\title{
5. 捜管または気管切開後に生じた気管狭窄の治療
}

\author{
*石 原 恒 夫
}

\section{Symposium: Treatment of Airway Stenosis \\ 5. Treatment of Tracheal Stenosis Following Intratracheal Intubation or Tracheostomy}

Tsuneo Ishihara, M.D.

Department of Surgery, School of Medicine, Keio University, Tokyo

There are three types of tracheal stenosis following intratracheal intubation and tracheostomy. They are; stomal stenosis which occurs at the site of tracheostomy, cuff level stenosis which occurs at the site of an inflated cuff of an intratracheal tube and tip stenosis at the site of a canula tip by irritation of a tracheal tube.

Up to date we have treated 3 cases of stomal stenosis, 3 cases of cuff level stenosis and one case of tip stenosis by means of tracheal reconstruction. In one case of stomal stenosis, tracheal stenosis recurred after reconstruction. This was due to an inadequate resection of the lesion of tracheal malacia. Operative results were satisfactory in the other cases.

Oblique tomography and flow-volume curve to diagnose tracheal stenosis and high speed ci ne tracheography to evaluate the state of postoperative airway passage were useful.

This paper deals with the methods of diagnosis and surgical technique for tracheal stenosis and also deals with methods to evaluate the airway passage following reconstruction of tracheal stenosis.

気管を広範囲に切除しても端々吻合で生じた欠損部 を修復しうることが明らかにされて以来 ${ }^{1,2)}$, 気管の切 除と再建における端々吻合術の応用は定着化しつつあ る。

気管は長さ約 $11 \mathrm{~cm}$ 気管軟骨の数は15〜 I9個，平均 16.5 個であるが3)，今日では10気管輪を含む気管（約 $60 \%$ ）を管状切除しても端々吻合によって修復するこ とが可能である ${ }^{1,2,4)}$ 。このように気管の病変に対する 外科的治療は往時からみれば急速に進歩したといえ る。

われわれは現在までに33例に対し気管成形術を行っ てきた, これら33例中の 7 例は插管または気管切開後 に気管狭窄が生じたものであった。本報告においては これらの挿管または気管切開後に発生した気管狭窄の 症例の狭窄のおこり方, 狭窄の診断法, 手術, 術後の *慶応義塾大学医学部外科
気道の評価について述べる。

\section{気管狭窄のおこり方}

気管切開後に生ずる気管狭窄のおこり方には 3 つの タイプがある。その 1 つは気管切開口を中心におこる 狭窄であり ${ }^{5,6)}, 1$ つは cuff があたっていた部分に生 ずる狭窄であり ${ }^{5,7 ~ 12)}, 1$ つは気管カニューレの先端の 刺激により生ずる肉芽狭窄である7)。

われわれの症例では気管切開口を中心に発生した気 管狭窄は 3 例あった。そのらちの 2 例では気管切開部 の気管軟骨が腐骨となり，この腐骨が中心となって肉 芽が増生していたものであった。残りの 1 例は気管切 開口のところで気管が強く屈曲し，そのために狭窄を 来たしたものであった。cuff の圧迫により生じた気管 狭窄は 3 例あった。1 例は頸髄損傷のため気管切開を 施行，11週間レスピレーターで機械呼吸を行い救命し 


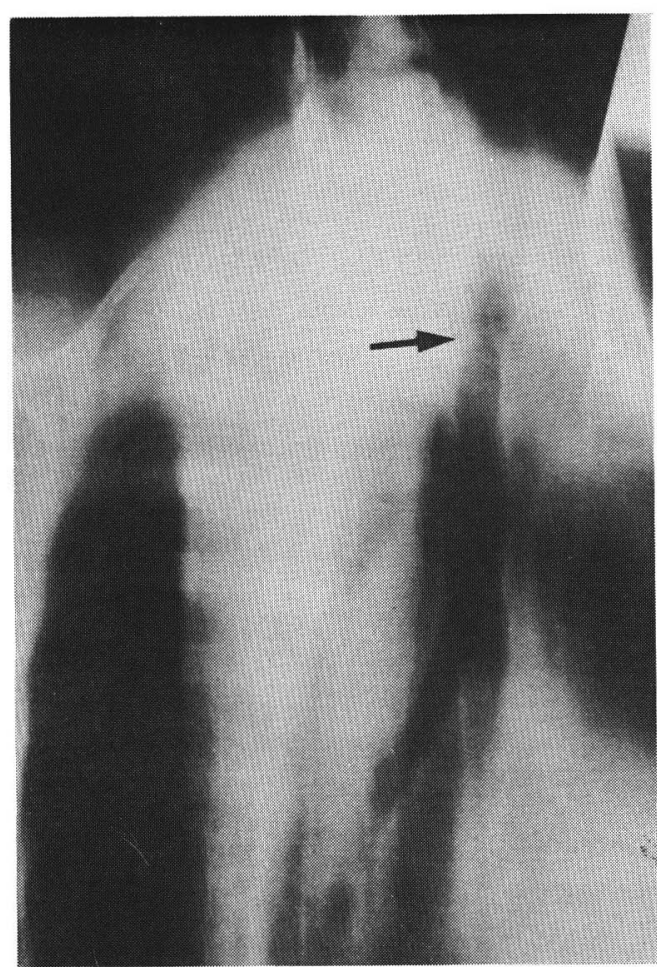

図1 気管チューブのカフが圧迫していた部 分に狭窄を生じた症例の斜断層写真。 矢印のところが狭窄している。

えたものであるが，機械呼吸を中止して気管カニュー レを抜去したところ， 3 週後に再び高度の呼吸困難が 現われた,検查の結果, cuff が圧迫していた部分の気管 が変性し, 肉芽が増生して気管狭窄を来たしているこ とが判明した。1 例はギランバレ一症候群のため呼吸 筋の麻㾝が発来, 気管切開を行って10日間レスピレー ターで人工呼吸を行った症例である。人工呼吸中止後 3 カ月を経過した頃から体動時に呼吸困難を感じるよ らになった。図 1，2 はこの症例の斜断層写真と切除 標本である。気管は頸胸移行部で高度记狭窄し, 内径 は約 $4 \mathrm{~mm}$ となっていた。残りの 1 例は高度の骨盤, 会陰損傷のため気管内挿管し，11日間レスピレーター を装着された症例である。人工呼吸により一命はとり とめたが, 2 力月過ぎた頃から喘鳴が出現し, 気管狭 窄が発見された。

気管カニューレの先端の刺激により気管内腔に肉芽 が増生した症例は 1 例あった。この症例は中脳水道閉 塞のため開頭術を施行, 7 力月間気管カニューレを抜 去できなかった 9 才の少年である。気管切開施行後 6 カ月をへた頃から呼気の著しい延長がみられるよらに
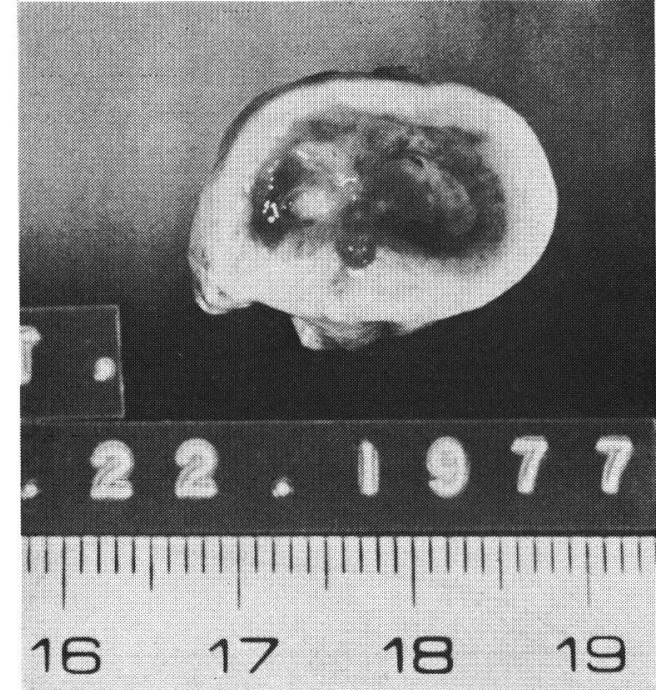

18

19

図 2 図1に示した症例の気管の切除標本。肺側

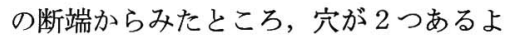
うにみえるが向って右側が狭窄している 気管内腔である。向って左側の白く光っ てみえるのは増生した肉芽の一部である。

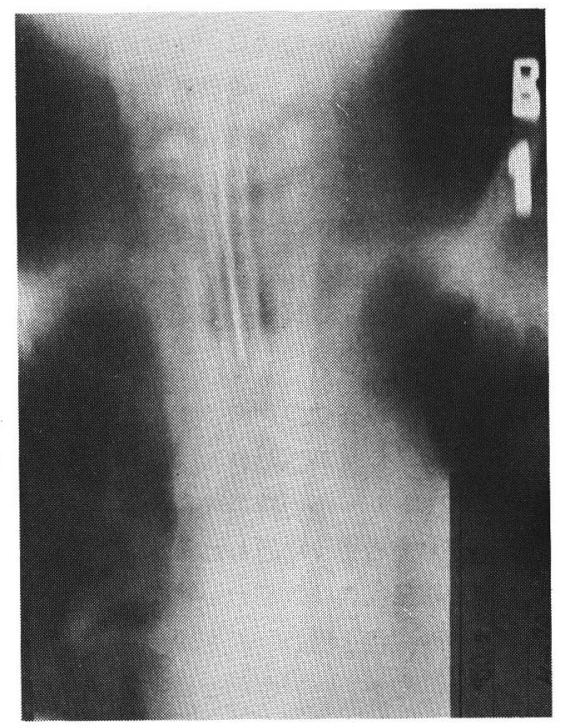

図 3 気管カニューレの先端の刺激で気管内腔 に肉芽狭窄の発生した症例の断層写真。 気管チューブの少し先に増生した肉芽が らっっている。

なり, 検查の結果, 気管分岐部より $2 \mathrm{~cm}$ 口側に隔壁 状に肉芽が増生し気管内腔が高度に狭窄している所見 がえられた。図 3 はこの症例の術前の断層写真であ る。 


\section{— 術 前 \\ -.-.-. 術 後 予測値}

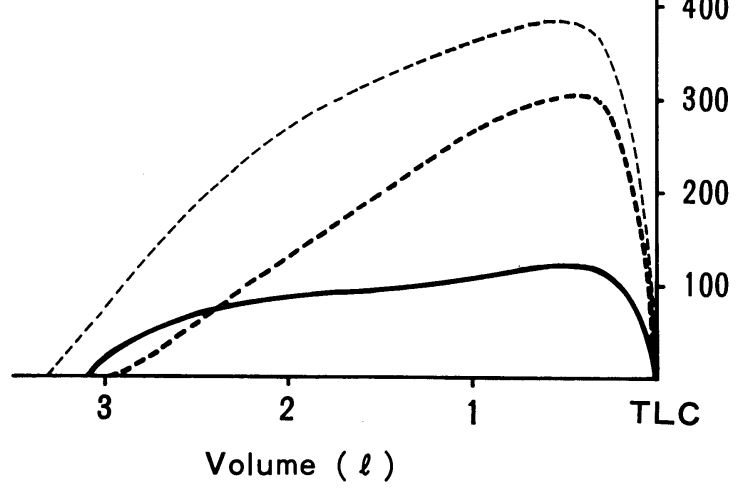

図 4 図 1 に示した症例の術前, 術後の flow-vclume 曲線および予測值の曲 線。術前の曲線は気管に狭窄がある ために台形を画いている。術後の曲 線はほぼ正常のパターンを示してい る。

\section{気管狭窄の診断}

気管切開口に生じた肉芽による狭窄では気管カニュ ーレを抜去したあと，比較的早い時期に喘息が出現す るので気管切開にもとづく狭窄の発生を早く発見し易 い。しかし, cuff の圧迫による気管狭窄は抜管後遅れ て発生する。われわれの症例では抜管後 1 例は 3 週 間， 1 例は 2 力月， 1 例は 3 力月をへた頃から狭窄症 状が出現してきた。抜管後 3 週間で高度の呼吸困難が 出現した 1 例は cuff の圧迫により膜様部が 変性し穿 孔していた。

気管カニューレの先端の刺激でおこる肉芽狭窄は 1 例のみであるが，症状が現われたのは挿管を 6 カ月つ ゔけた頃からであり，この種の狭窄の発生には長時間 の刺激が必要であるように思われた。

気管狭窄の初発症状は大部分が喘鳴であった。最初 から呼吸困難の症状を現わしたものもあるが，多くは 喘鳴が先行し, やがて呼吸困難を自覚するようであっ た。呼気の延長から他覚的に気管狭窄を疑われたもの もあった。

気管狭窄と診断する方法にはいろいろあるが，われ われは主としてX線写真で診断している。通常の写真 でもよいが，狭窄部が縦隔内にある症例では $55^{\circ}$ の深 い斜位で断層写真をとっている。梁い斜位で断層写真 をとると，図 1 に示したように気管は全長にわたり 1 つの平面に描出されるので狭窄の診断には非常に有用 である。また狭窄の機能的診断には, flow-volume 曲 線の測定を応用している。flow-volume 曲線は本来末 梢の気道病変の検出のために考え出されたものである が，気管の狭窄の診断にも役立つすぐれた検査方法で ある。断層写真が平面的であるのにに対して flowvolume 曲線は立体的に狭窄の程度をわれわれに教え てくれる。図 4 は図 1 に示した症例の気管成形術前後 の flow-volume 曲線である。この検査は被検者が吸 いこんだ空気を一気に吐き出すだけの簡単なもので被 検者にはほとんど苦痛を与えない。図 4 の予測值の曲 線に示したように正常では呼気のはじめに吸いこんだ 空気の大部分が早い速度で呼出されて行くので，曲線 は急速に上昇し，ピークを過ぎると徐々に下降して行 く。縦軸は呼気流量であり, 横軸は呼出された肺気量 である。気管の一部に狭窄があると，吸いこんだ空気 を一気に吐き出そうとしても狭窄部が抵抗となって十 分に空気を呼出することができない。したがって曲線 は山の低い台形となり，明らかに正常とは異ったパタ ーンを示す。そして狭窄の程度がひどくなる程，曲線 は低い台形を画くようになる。

\section{気管狭窄の手術}

気管分岐部より $2 \mathrm{~cm}$ 口側の気管に隔壁状の狭窄を 生じた 1 例に対しては右開胸で手術を行ったが，他の 6 例に対してはすべて前頸部に襟状切開を加えて気管 狭窄部に到達した。

頸部気管に高度の狭窄のある症例では通常の気管内 麻酔で手術をはじめることはできない。そのためにわ 


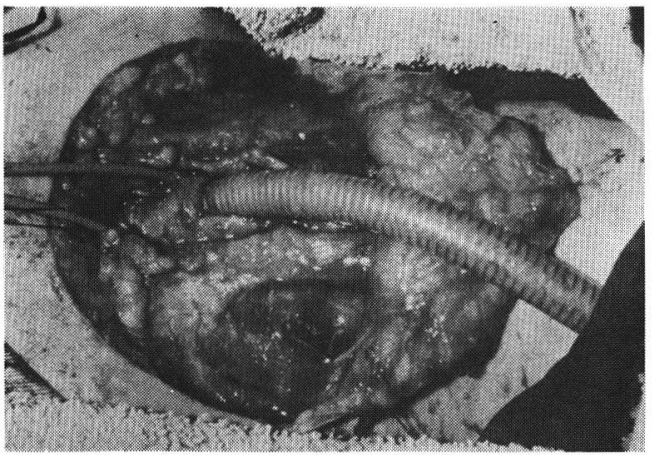

図 5 気管狭窄部より末梢に気管切開を行い, 手術野から消毒した気管チューブを気管 内に挿入したところ

れわれは局所麻酔で手術をはじめ，気管に到達したあ と気管狭窄部の末梢に気管切開を行い，術野から消毒 した気管チューブを肺側の気管に挿入して全身麻痺に 切りかえている(図5)。

ついで気管の病変部を全周剝離し, 切除長に応じて 上下の気管を気管固有鞘の内側で剝離して気管に可動 性を与える。切除部以外では気管膜様部の剝離は原則 として行っていない。気管切開後の気管狭窄例では悪 性腫瘍による気管狭窄例と異り, 一般に切除範囲は狭 いので, われわれは気管を広範囲に剝離する必要を感 じたことはあまりない。

気管の剝離が終ったならば気管病変部を切除し, 気 管の端々吻合にかかる, まず後壁側に縫合系をかけ, 半周かけたところで,気管チューブの入れかえを行う。 術野から肺側の気管断端に気管チューブを挿入したま まで縫合糸を全周にかけることは面倒である。その ために新たな消毒済の気管チューブを気管の口側端か ら口腔に向って逆行性に挿入する。引きつづいて先に 肺側の気管端に挿入してあったチューブを抜去して逆 行挿管したチューブの先端を肺側の気管端に挿入す る。こうすると形は普通の気管内挿管と同じになり, 気管チューブが縫合操作の妨げとなることもないし, また消毒したチューブが捙入されてあるので術野が污 染されることもない。この状態で前壁側に縫合系をか ける。

縫合糸は針付きのプロリーンを用い，粘膜下に針を 通して気管内腔に系が出ないようにしている。全周に 縫合采をかけ終ったならば，あらかじめ両断端にかけ ておいた支持糸をひき，気管の両断端が接着するよう にして縫合采を結禁する。結紮する縫合系に緊張がか からぬようにするためである。

われわれは後側の半周の縫合糸の結禁が終ったとこ
ろで，支持糸を一度ゆるめて後壁側の縫合糸の結紮の 状態を吻合口から䙼くようにして直視下に調へててい る。結禁した縫合糸の締り具合, 粘膜の接着の状態を みるのである。後壁側の縫合の状態が良ければ再び支 持糸をひいて前壁側の縫合糸を結椞する。吻合が終了 したならば創内を洗浄し，空気もれの有無を調べ，ド レーンを挿入して創を 2 層に閉鎖する。以上がわれわ れが常用している手術手技である。

\section{術後の気道の評価}

気管端々吻合後の気管吻合部の評価にあたっては前 述したX線写真と flow-volume 曲線を用いているが, 気管の内径あるいは吻合部の断面積の評価とは別に, われわれは気管造影映画を用いて吻合気管の機能的動

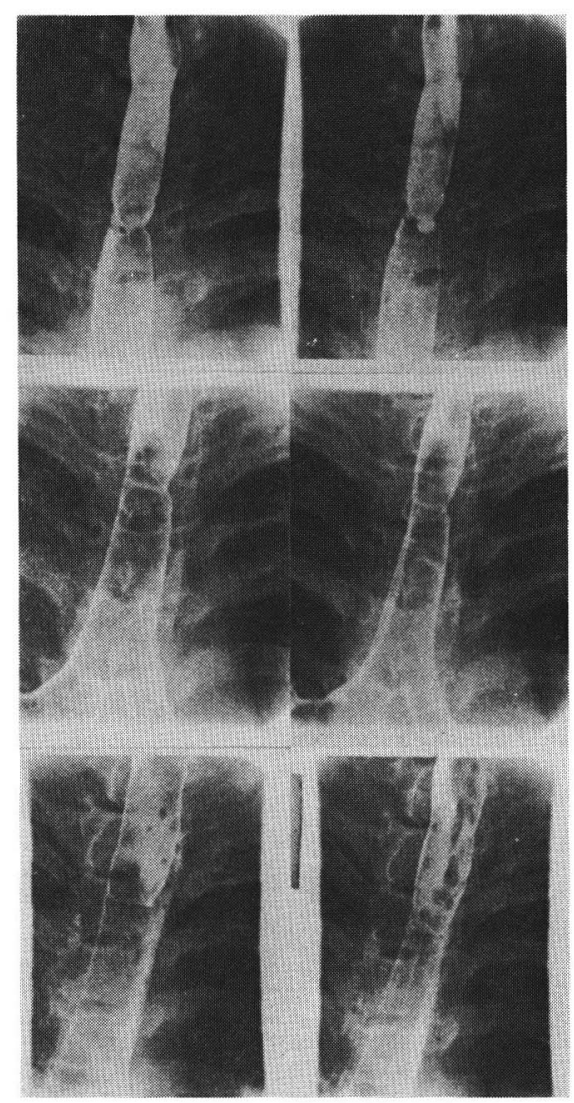

図6気管造影映画の1コマを焼付けたもの， 上段は術前, 中段は術後 1 力月, 下段は 術後 4 カ月に撮影したものである。向っ て右側は深呼気時, 左側は深吸気時であ る術前の呼気時の写真では狭窄があるた めに狭窄部より末梢の気管は収縮できな w。 
態を検査している。この方法は造影剤を用いて気管造 影を行い，患者に激しく咳嗽をするように促がし，咳 嗽時の気管の動きを 1 秒間 100 コマの高速度で撮影す るのである。図 6 は術前, 術後 1 力月, 術後 4 力月に 撮影した気管造影映画の最大吸気時, 最大呼気時の 1 コマをそれぞれ焼付けたものである。術前のフィルム でみると, 最大呼気時においても狭窄部より末梢の気 管は十分に呼気を呼出できないために収縮しえない。 術後 1 カ月のフィルムでは狭窄が解除されたためにこ れらの変化は消失しているが，気管のレリーフは一般 に硬く, 吻合部の動きも少い。しかし, 術後 4 力月の フィルムでは吻合部は咳嗽に従って上下に移動し気管 壁も弾性を恢復してきているようにみえる。すなわ ち, 術後 4 力月頃になると気管は全般にわたり本来の 機能を取り戻しているようである。

\section{おわりに}

挿管または気管切開後に発生した気管狭 窄につい て, 症例を呈示しながら, 気管狭窄のおこり方, その 診断および手術 (管状切除, 端々吻合), 術後の気道 の評価について述べた。

\section{文献}

1) Grillo, H.C. et al.: Extensive resection and reconstruction of mediastinal trachea without prosthesis or graft: an anatomical study in man. J. Thorac. Cardiovasc. Surg., 48 : 741-749, 1964.

2) Naef, A.P.: Extensive tracheal resection and tracheo-bronchial reconstruction. Ann. Thorac. Surg., $8: 391-401,1969$.

3 ) 古泉桂四郎：気管の伸長能に関する計測的研究, 日気食会報，17・294-304，1967.

4 ）石原恒夫ほか：気管悪性腫瘍に対する外科的治 療, 日気食会報, $28: 254-258,1977$.

5 ) Fishman, N.H. et al.: Postintubation tracheal stenosis. Ann. Thorac. Surg., 8:47-56, 1969.

6 ) 石原恒夫：気管狭窄に対寸る気管成形術の応用, 手術, $24: 1452-1458,1970$.

7 ) 石原恒夫ほか：気管気管支成形術, 胸 部外科, $28: 761-772,1975$.

8 ) Pearson, F.G. \& Andrew, M.J.: Detection and management of tracheal stenosis following cuffed tube tracheostomy. Ann. Thorac. Surg., 12 : 359-374, 1971.

9 ) Grillo, H.C. et al.: A low-pressure cuff for tracheostomy tubes to minimize tracheal injury. A comparative clinical trial. J. Thorac. Cardiovasc. Surg., $62:$ 898-907, 1971.

10) Goldberg, M. \& Pearson, F.G.: Pathogenesis of tracheal stenosis following tracheostomy with cuffed tube. An experimental study in dogs. Thorax, $27: 678-691,1972$.

11) Ching, N.P.H. et al.: Endotraceeal damage during continuous ventilatory support. Ann. Surg., 179 : 123-127, 1974.

12) Dunn, C.R. et al.: Determinants of tracheal injury by cuffed tracheostomy tubes. Chest, 65 : 128-135, 1974.

(別刷請求： $\begin{array}{r}7 \\ 160 \text { 東京都新宿区信濃町35 } \\ \text { 慶応義熟大学医学部外科 }\end{array}$ 